\title{
A typology of online care platforms for community-dwelling older adults in the Netherlands: A scoping review
}

\author{
Sarah Willard MSc $c^{\mathrm{a}, \mathrm{b}, *}$ \\ Erik van Rossum $\mathrm{PhD}^{\mathrm{a}, \mathrm{b}}$ \\ Marieke Spreeuwenberg $\mathrm{PhD}^{\mathrm{a}, \mathrm{b}}$ \\ Luc de Witte PhD ${ }^{\mathrm{a}, \mathrm{c}}$
}

\begin{abstract}
${ }^{a}$ Centre of Innovative Care and Technology (EIZT), Zuyd University of Applied Sciences, Henri Dunantstraat 2, 6419PB, Heerlen, The Netherlands; ${ }^{b}$ School CAPHRI, Care and Public Health Research Institute (CAPHRI), Faculty of Health, Medicine and Life Sciences, Maastricht University, Maastricht, the Netherlands; 'Centre for Assistive Technology and Connected Healthcare (CATCH), University of Sheffield, Sheffield, United Kingdom; *Corresponding author: sarah.willard@zuyd.nl
\end{abstract}

\begin{abstract}
S. Willard, E. van Rossum, M. Spreeuwenberg, L. de Witte. A typology of online care platforms for community-dwelling older adults in the Netherlands: A scoping review. Gerontechnology 2019;18(2):122-141; https://doi.org/10.4017/gt.2019.18.3.001.00 Background Due to demographic transitions and budget restraints, it is now necessary to search for comprehensive new strategies, in order to constitute a sustainable healthcare system. Recently, various online care platforms for community-dwelling older adults were introduced in several European countries. These platforms have aimed at solidifying social cohesion in the community, so as to support the older adults in coordinating or managing their care and to enhance the self-reliance of these older adults. Consequently, these platforms might contribute to a more sustainable healthcare system. The main research question of this study was twofold: Which online care platforms for older adults are available in the Netherlands and what are their characteristics? Methods The researchers have performed a scoping review of the online care platforms in the Netherlands, according to the six steps of Arksey \& O'Malley (2005), which were as follows: (1) Identifying the research question; (2) Identifying any relevant studies; (3) Selecting the studies; (4) Charting the data; (5) Collating, summarising and reporting on the results; together with (6) consultations with the relevant stakeholders. The study searched for evidence in online scientific databases (Phase 1) and on the Internet (Phase 2). The relevant studies that were published between February 2012 and October 2017 were included. Results The review resulted in an overview of 21 care platforms, for which 3 types were identified: (1) Community Care Platforms; (2) Care Network Platforms; and (3) System Integrator Platforms. Conclusion This typology of platforms can guide users - for instance, older adults, care professionals, informal caregivers and municipalities, in choosing a suitable care platform, i.e. the typology gives users insight into the functionalities, goals and target groups which allows them to choose a platform that matches their needs. As far as the authors know, no studies have previously reported on the effects of the online care platforms for older adults in the Netherlands, so further research is required on their impacts and on their benefits.
\end{abstract}

Keywords: older adults, community-dwelling, online platform, ICT

\section{INTRODUCTION}

Due to an ageing of the European population, transitions in long-term care have been implemented in which governments have promoted deinstitutionalisation, by emphasising individuals own responsibilities and by activating citizens to help each other (Bankauskaite, Dubois, \& Saltman, 2007; Companje, 2013; Foster \& Walker, 2015; Newman \& Tonkens, 2011; Van der Schoot, 2014). These transitions have major consequences for the positions and the roles of community-dwelling older adults. Care responsibilities are shifting from the health care system, to the older adults themselves, and their social networks. Self-management competencies are highly valued and these older adults are encouraged to live independently in their own place for as long as possible, i.e. they are encouraged to 
Table 1. Description of the platform characteristics

\section{Platform characteristics and their description}

The name of the online platform.

The name of the platform's owner or administrator (e.g. company name).

Goal of the platform.

Target group: the people for whom the online platform is (initially) intended.

End users: the people who actually use the online platform (this may include other people than the targeted group).

Information*: functionalities that provide information to the user (one-way).

Communication*: functionalities that enable the exchange of information between two or more users (two-way).

Commercial services*: functionalities in which entrepreneurs or companies offer their product(s) with the objective of making a profit.

Community care*: Functionalities that aim to improve social cohesion on a neighbourhood level, or that aim to improve the wellbeing ("happiness") and the comfort of the users.

Health care services*: functionalities that aim to support the users in their health (care).

Monitoring*: functionalities that enable users, or people in their network, to notice changes in their personal environment or physical wellbeing.

Recreation: functionalities that enable users to amuse or entertain themselves.

Focus of the platform: whether the platform is more community oriented, health care oriented, focussed on supporting care-networks, or on a combination of the preceding.

Personalisation: whether the user has the possibility to customise the platform to their own preferences.

Status: the development stage of the platform and its lifespan.

Distribution/range: geographical area in which the platform is most used, number of users, etc.

Costs: costs for the purchase and the maintenance of the platforms' software and the expenses for the end user.

Hardware/software: whether the online platform is accessible via an application, a website or by special hardware.

Privacy: information about the availability of a privacy statement or policy.

Evaluation: the extent to which (the effects of) the online platform has been evaluated.

${ }^{*}=$ platform functionality, which was taken into account during the selection procedures dwelling older adults. These online platforms for older adults have various objectives: a) to solidify social cohesion in the community; b) to support older adults in coordinating or managing their own care; and c) to enhance the self-reliance of these older adults. Consequently, these online platforms might possibly contribute to a more sustainable healthcare system (Robben et al., 2013; Vedel, Akhlaghpour, Vaghefi, Bergman, \& Lapointe, 2013; Willard et al., 2018). However, there has been little research conducted on the availability of online platforms for older adults and their characteristics, functionalities, usability and effects, in order to guide older adults in choosing a suitable platform. There is a large number of platforms in the Netherlands and 'age-in-place' (Cramm, Twisk, \& Nieboer, 2014; Van Hees, 2017).

In this more 'participatory society', it is now necessary to search for comprehensive new and smart strategies, in order to constitute a sustainable and affordable health care system. Technology can support these strategies. A technological solution, whereof many were recently introduced in several European countries (e.g. Germany (Boll \& Brune, 2016), England (GrandCare, 2016), Belgium (CareLivingLabs, 2018) and the Netherlands (Krijgsman, Eertink, Leeuw, \& Zondervan, 2012; Makai et al., 2014a; Makai et al., 2014b; De Jong, 2015)) are online care platforms for community- the majority of them suggest that they aim to support community dwelling older adults. As they all communicate about this objective in the same way the misconception arises that they also work in the same way. That however, is not the case: their actual aims and functionalities vary. The authors believe that knowledge about the Dutch 'case' is relevant for the end-users, start-ups, additional research groups and the policy makers, in other countries as well.

The main research question of this study was twofold: Which online care platforms for older adults are available in the Netherlands and what are their characteristics? 
765 potentially relevant documents

730: scientific databases

(SD)

35. grey literature (GL) retrieved from the Internet

81 potentially relevant documents (46: SD. $35: \mathrm{GL})$

19 potentially relevant online platform descriptions (19: GL)

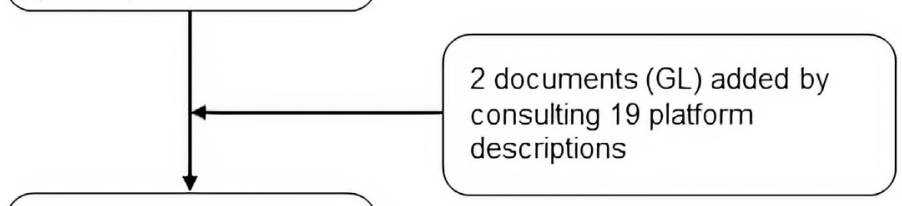

21 webpages/ online platform descriptions included in review (21: GL)

Figure 1. Flowchart of the Selection Process

\section{Methods}

A scoping review (Arksey \& O'Malley, 2005; Colquhoun, Levac, \& O'Brien, 2010; Grant \& Booth, 2009) was conducted, in order to summarise 'the state of the science' regarding the online care platforms for older adults in the Netherlands and to provide an overview of these platforms. Scoping reviews are "specifically designed to identify gaps in the evidence base (...) and they may also summarise and dissemi-

62 documents excluded (46: SD, 16: GL) based on abstract or platform description because:

- Not a platform $(\mathrm{N}=25)$

Not a Dutch platform

Not for older adults ( $\mathrm{N}=2)$ adults with disease or condition ( $\mathrm{N}=14)$

No longer online or available $(\mathrm{N}=5)$

Limited No of functionalities $(\mathrm{N}=6)$

Restricted to members or clients of organisation $(\mathrm{N}=5)$

2 documents (GL) added by consulting 19 platform descriptions nate research findings" (Arksey \& O'Malley, 2005, p. 21). This scoping review was performed according to the six steps of Arksey \& O'Malley (2005), which were as follows: identifying the research question; identifying the relevant studies; selecting the studies; charting the data; collating, summarising and reporting on the results; together with consultations with the relevant stakeholders.

\section{Identifying the research ques- tion}

This research focused on answering two research questions: (1) Which online care platforms for older adults are available in the Netherlands? and (2) What are their characteristics?

\section{Identifying the relevant studies}

In this review, different sources were consulted when searching for the researched evidence: that is, online scientific databases for the scientific literature (Phase 1) and on the Internet for the 'greyliterature' (Phase 2).

\section{Phase 1 -Database searches} First of all, a review of the scientific literature in the databases of PubMed and PsycINFO was conducted. In order to identify the study's population and to demarcate the geographical area, the MESH terms "aged" and "aged 80 and over" were combined with the term "Netherlands". So as to keep the scope for the research as wide as possible, the online care platforms were specified, by using broad terms such as "ICT-platform", "online platform", "eHealth platform", "eCommunity", "online health", "web based platform", "services platform", "web based health", "web based social networking", "online care communities", "online social health", "healthcare platform", "care platform", "self-management tools" and these related MESH terms were combined with OR. The searches for the study's population and the interventions were, consequently, combined with AND - and they were restricted to approximately a 5 year period (February 2012 - October 2017). The searches were restricted to 
Table 2. Characteristics of the Online Care Platforms

\begin{tabular}{|c|c|c|c|}
\hline No. & Platform & Goal & End users \\
\hline \multicolumn{4}{|c|}{ CATEGORY 1 COMMUNITY CARE } \\
\hline 1 & Community Welfare & $\begin{array}{l}\text { To enhance social cohesion on a } \\
\text { neighbourhood level. }\end{array}$ & $\begin{array}{l}\text { Local residents, people in need of } \\
\text { care, volunteers, social workers, } \\
\text { entrepreneurs and communities. }\end{array}$ \\
\hline 2 & $\begin{array}{l}\text { Trivici Welfare Portal } \\
\text { According to the example } \\
\text { of the 'Burum Portal' }\end{array}$ & $\begin{array}{l}\text { To enhance social cohesion on a } \\
\text { neighbourhood level. }\end{array}$ & $\begin{array}{l}\text { Local residents, healthcare and } \\
\text { welfare organisations, housing } \\
\text { corporations and local } \\
\text { municipalities. }\end{array}$ \\
\hline 3 & Son and Breugel Connect & $\begin{array}{l}\text { sTo enhance the welfare of the } \\
\text { community through connecting local } \\
\text { residents and through mobilisation. }\end{array}$ & $\begin{array}{l}\text { Local residents, networks and } \\
\text { entrepreneurs. }\end{array}$ \\
\hline 4 & Sevagram Connect & $\begin{array}{l}\text { To enhance mutual (informal) care by } \\
\text { 'connecting' (health) care demands and } \\
\text { informal caregivers. }\end{array}$ & $\begin{array}{l}\text { Local residents, healthcare } \\
\text { providers, Sevagram's clients, } \\
\text { informal caregivers and } \\
\text { entrepreneurs. }\end{array}$ \\
\hline & My Neighbourhood & $\begin{array}{l}\text { To offer an adequate and an accessible } \\
\text { interactive communication channel for } \\
\text { a community (i.e. to integrate services } \\
\text { and information). }\end{array}$ & $\begin{array}{l}\text { Local residents, entrepreneurs, } \\
\text { health and welfare organisations, } \\
\text { municipalities }\end{array}$ \\
\hline 6 & Community Connect & $\begin{array}{l}\text { To connect local residents by bringing } \\
\text { together (health) care demands with } \\
\text { (informal) services. }\end{array}$ & $\begin{array}{l}\text { Local residents, resident- } \\
\text { organisations, non-profit } \\
\text { organisations, local initiatives and } \\
\text { municipalities. }\end{array}$ \\
\hline 7 & Region Online & $\begin{array}{l}\text { To support local communities in } \\
\text { creating a better and a more social } \\
\text { living environment. }\end{array}$ & $\begin{array}{l}\text { Local residents, entrepreneurs, } \\
\text { non-profit organisations and } \\
\text { municipalities. }\end{array}$ \\
\hline 8 & Wiki Community & $\begin{array}{l}\text { To enhance self-management } \\
\text { competencies of the local residents and } \\
\text { to facilitate these residents to age-in- } \\
\text { place. }\end{array}$ & $\begin{array}{l}\text { Local residents, informal } \\
\text { caregivers, healthcare } \\
\text { organisations and volunteers. }\end{array}$ \\
\hline & WeHelpen & $\begin{array}{l}\text { To encourage and facilitate community- } \\
\text { dwellers in helping each other. }\end{array}$ & $\begin{array}{l}\text { People who help someone or } \\
\text { receive help (e.g. informal } \\
\text { caregivers, volunteers and people } \\
\text { in need of care). }\end{array}$ \\
\hline
\end{tabular}

\section{CATEGORY 2 SYSTEM INTEGRATOR}

\begin{tabular}{lll}
\hline 10 Cubigo & To support vulnerable community- & Older adults, informal caregivers \\
dwelling people in their independence & volunteers, municipalities, service \\
and their health, by stimulating self-care & providers, healthcare and welfare \\
and providing reliable information, & organisations. \\
products and services. &
\end{tabular}

a 5 year period as the goal was to provide a recent overview of the Dutch field of Online Care Platforms. All of this resulted in the final search. The references in the articles were checked for other relevant platforms.

Phase 2 - Searching on the internet

In the second phase, the researchers extensively searched on the Internet (via Google and Google Scholar) for reports, web pages, or online descriptions, about the online care platforms. While searching for this grey-literature, the same terms that were used during the search in the PubMed and PsycINFO databases were employed. The references in the documents were again checked for other relevant platforms. In this second phase,
3 researchers worked together in reviewing and assessing the online platforms, i.e. they all independently searched for information on the online platforms and they convened on a regular basis, in order to align their findings on the terminologies, the categories and the characterisations of the data. These researchers applied inductive reasoning', moving from specific observations, to broader generalisations (Bryman, 2016).

\section{Selecting the studies}

A report on an online platform, whether it was a scientific article or not, was suitable for inclusion, if it met the following inclusion criteria. The online platform: (1) had to have at least two functionalities, e.g. information on 
Table 2. Characteristics of the Online Care Platforms (cont.)

\begin{tabular}{|c|c|c|}
\hline Platform & Goal & End users \\
\hline \multicolumn{3}{|c|}{ CATEGORY 3 CARE NETWORKS } \\
\hline 11 Caren & $\begin{array}{l}\text { To facilitate and support people in the need } \\
\text { of care and at coordinating and arranging } \\
\text { their own (health) care }\end{array}$ & $\begin{array}{l}\text { People in need of (health) care, informal } \\
\text { caregivers, volunteers, healthcare } \\
\text { professionals, social workers. }\end{array}$ \\
\hline 12 HelloCare & $\begin{array}{l}\text { To attune their (health) care with family } \\
\text { members, acquaintances, friends and home } \\
\text { care and to facilitate collaboration. }\end{array}$ & $\begin{array}{l}\text { People who live at home and who are in } \\
\text { the need of (health) care. Informal } \\
\text { caregivers and healthcare professionals. }\end{array}$ \\
\hline 13 Companion & To facilitate older adults to age-in-place. & $\begin{array}{l}\text { Older adults, their informal caregivers and } \\
\text { healthcare professionals and social workers. }\end{array}$ \\
\hline 14 Quli & $\begin{array}{l}\text { To enhance self-management competencies } \\
\text { of frail individuals. }\end{array}$ & $\begin{array}{l}\text { People in need of (health) care, informal } \\
\text { caregivers, family, friends, healthcare } \\
\text { professionals, healthcare organisations and } \\
\text { municipalities. }\end{array}$ \\
\hline 15 ShareCare & $\begin{array}{l}\text { To support informal caregivers who wish to } \\
\text { coordinate their collaborations and (health) } \\
\text { care with a person they care for. }\end{array}$ & $\begin{array}{l}\text { People in need of (health) care, informal } \\
\text { caregivers, family, friends, volunteers, } \\
\text { healthcare professionals, social workers, } \\
\text { healthcare organisations. }\end{array}$ \\
\hline 16 Fello & $\begin{array}{l}\text { To activate and support the social networks } \\
\text { of people who are in need of care. }\end{array}$ & $\begin{array}{l}\text { People in need of (health) care, informal } \\
\text { caregivers, family. }\end{array}$ \\
\hline 17 FamilyNet & $\begin{array}{l}\text { To support informal caregivers and } \\
\text { healthcare professionals who wish to } \\
\text { coordinate their collaborations and (health) } \\
\text { care. }\end{array}$ & $\begin{array}{l}\text { People in need of (health) care, informal } \\
\text { caregivers, healthcare professionals and } \\
\text { organisations. }\end{array}$ \\
\hline
\end{tabular}

18 Caregivers To facilitate older adults to age-in-place by

Plan bringing all of the caregivers together in one online environment.

volunteers, friends, healthcare professionals and healthcare organisations.

19 MiBida To improve the collaboration and the People in need of (health) care, informal communications among informal caregivers caregivers, family, friends, healthcare and thereby contributing to the quality of professionals and home care.

life of those people in the need of care.

20 BetterApp To support individuals in actively working Vulnerable individuals, informal caregivers on their (health) goals in a collaboration and healthcare professionals.

with informal caregivers and healthcare professionals.

21 Netty To improve the collaboration and the Informal caregivers, healthcare communications among informal caregivers professionals, family, friends. People in and healthcare professionals, thereby contributing to the quality of life of people platform. who are in need of care.

community activities and a tool to communicate with a caregiver (a video calling service); (2) had to be easily accessible for older adults and be available for everyone who wanted to subscribe; (3) had to be aimed at improving (health) care and/or wellbeing; (4) had to be interactive; and (5) had to be available and currently in use in the Netherlands. Researched documents were excluded if the online platform: (1) was intended for older adults, suffering from specific conditions or diseases (e.g. diabetes, heart disease, dementia, and so forth); and (2) was merely intended for older adults living in a nursing home or in a care facility (i.e. for certain clients or members only).

\section{Charting the data, summarising, and report- ing on the findings}

Each included online platform was described according to a set of 20 characteristics (Table 1), such as the platform's goal, its target group, its end users and its functionalities. As described in Phase 2, these characteristics were determined by using an inductive approach, for instance, the characteristics were extracted from and observed in the collected data about online platforms. The 3 researchers from Phase 2 independently described each platform. These descriptions were then compared; any discrepancies were solved by discussing the most appropriate and suitable description. 


\section{A typology of online care platforms}

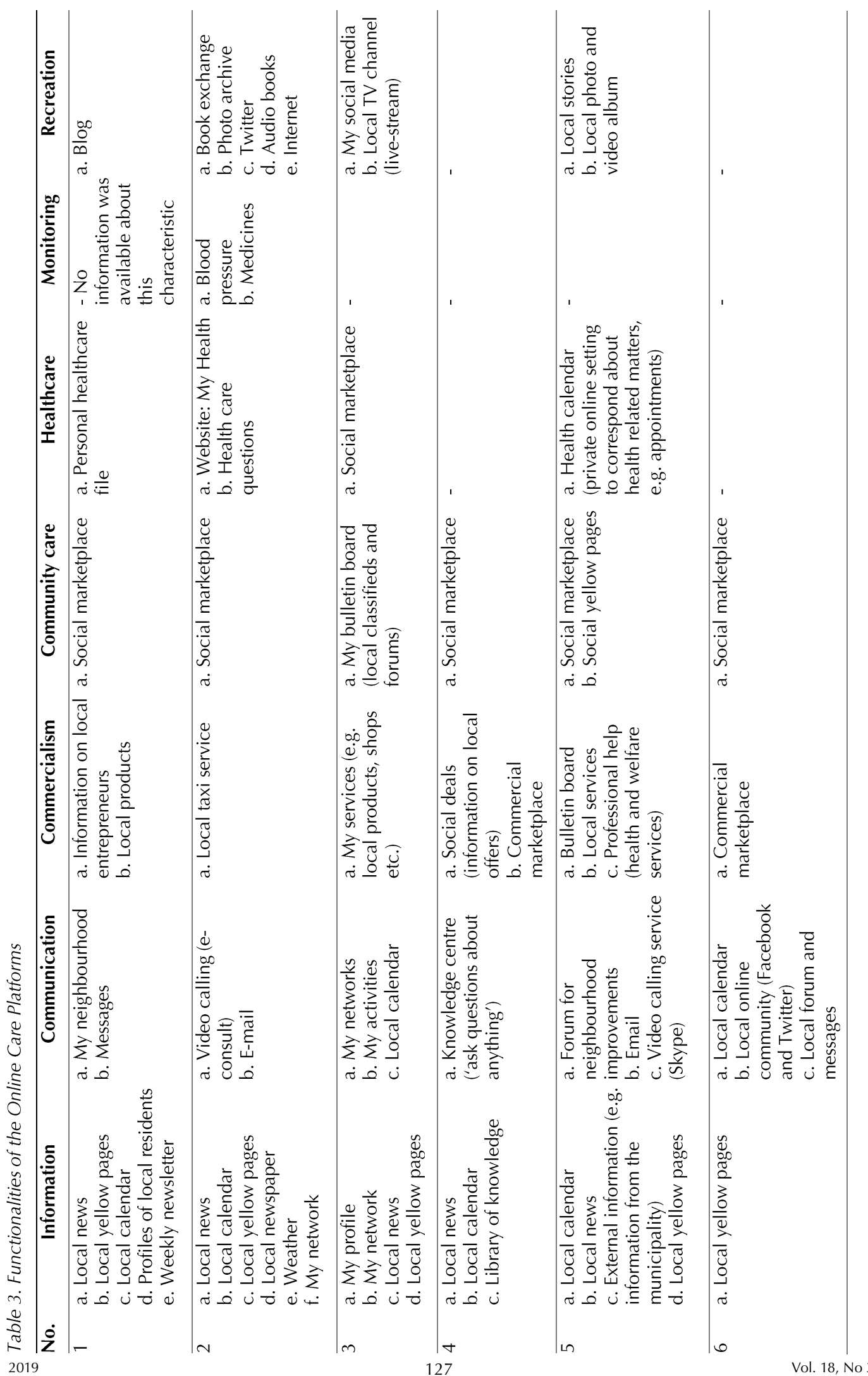




\section{A typology of online care platforms}

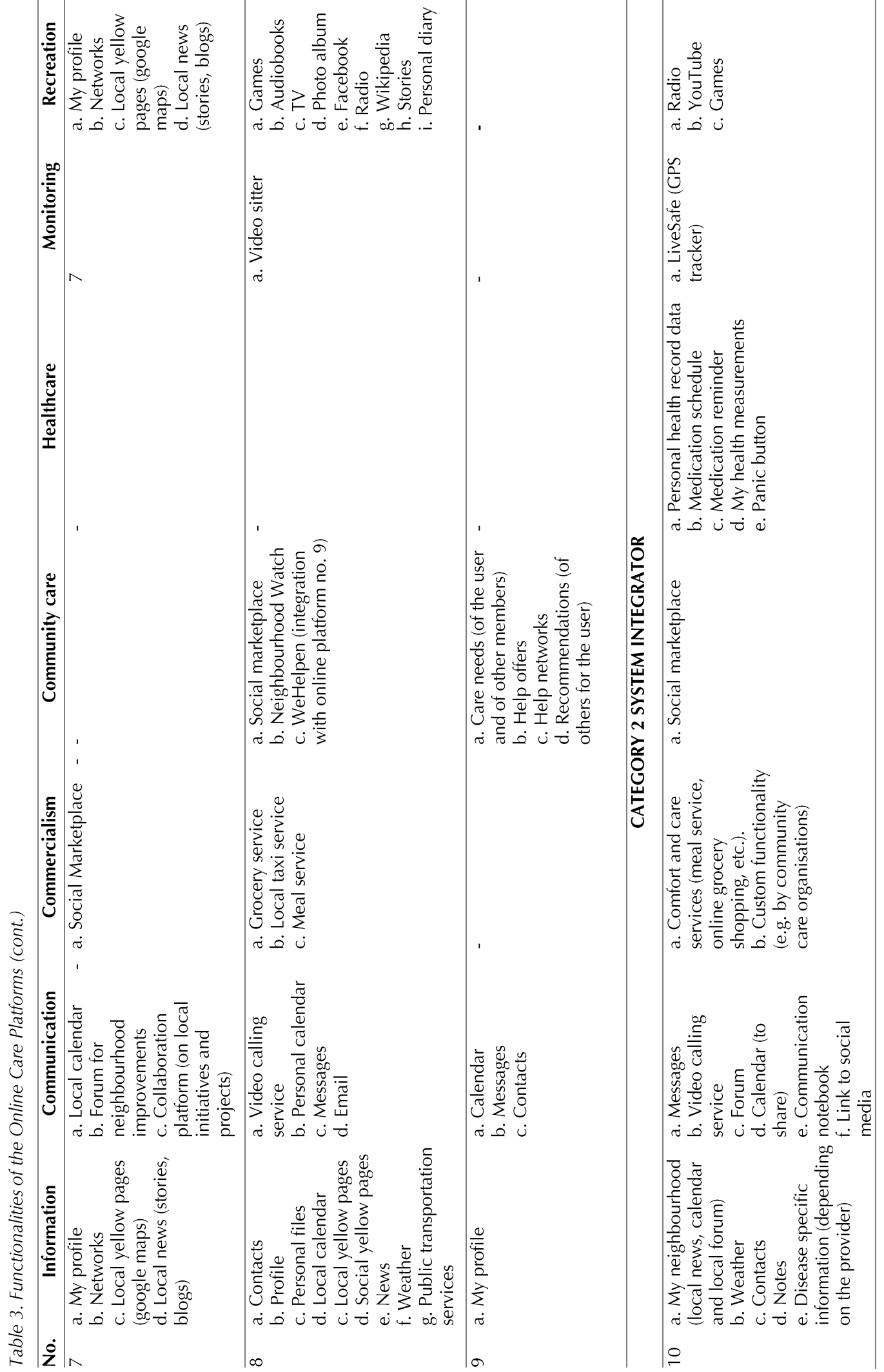




\section{A typology of online care platforms}

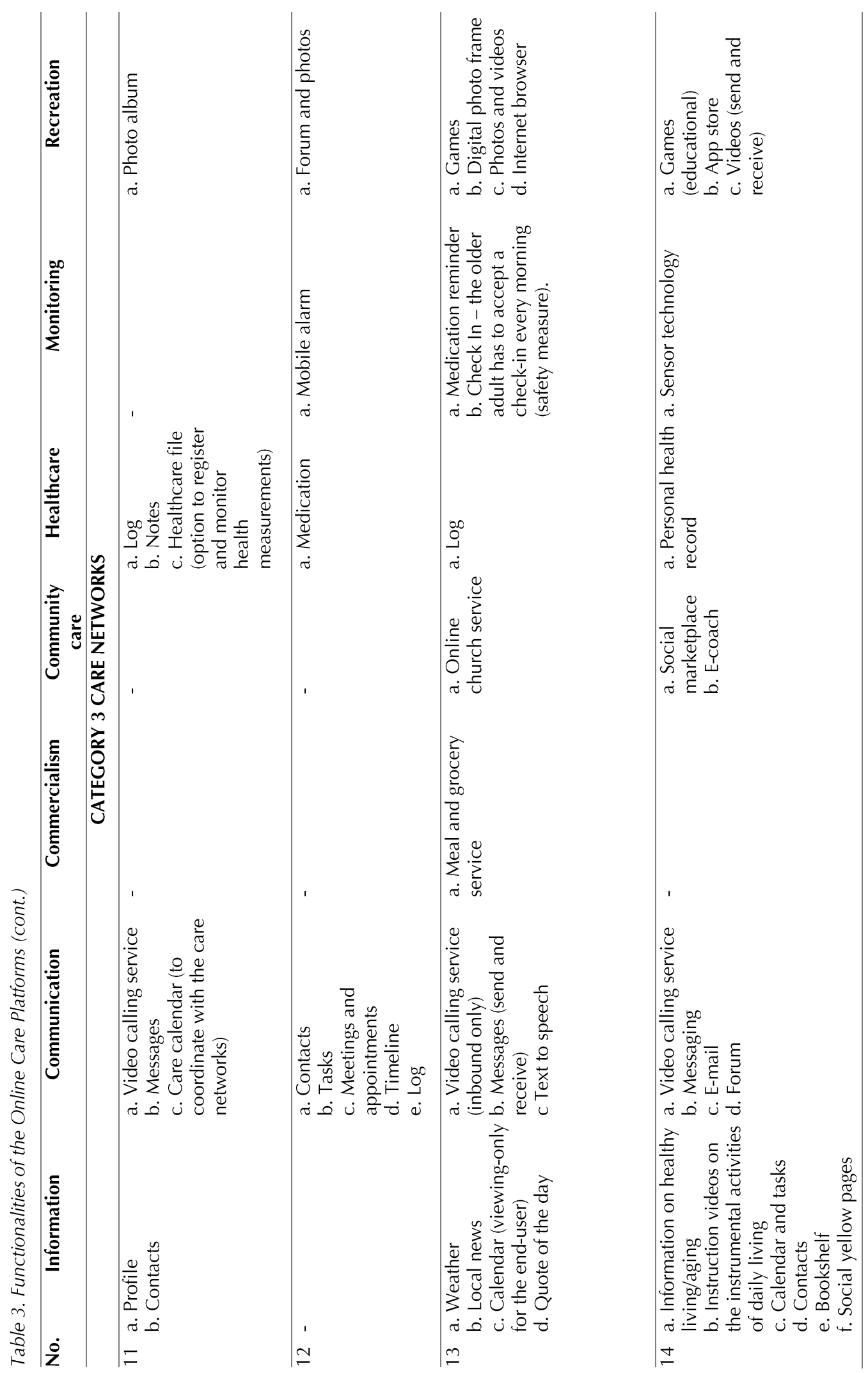




\section{A typology of online care platforms}

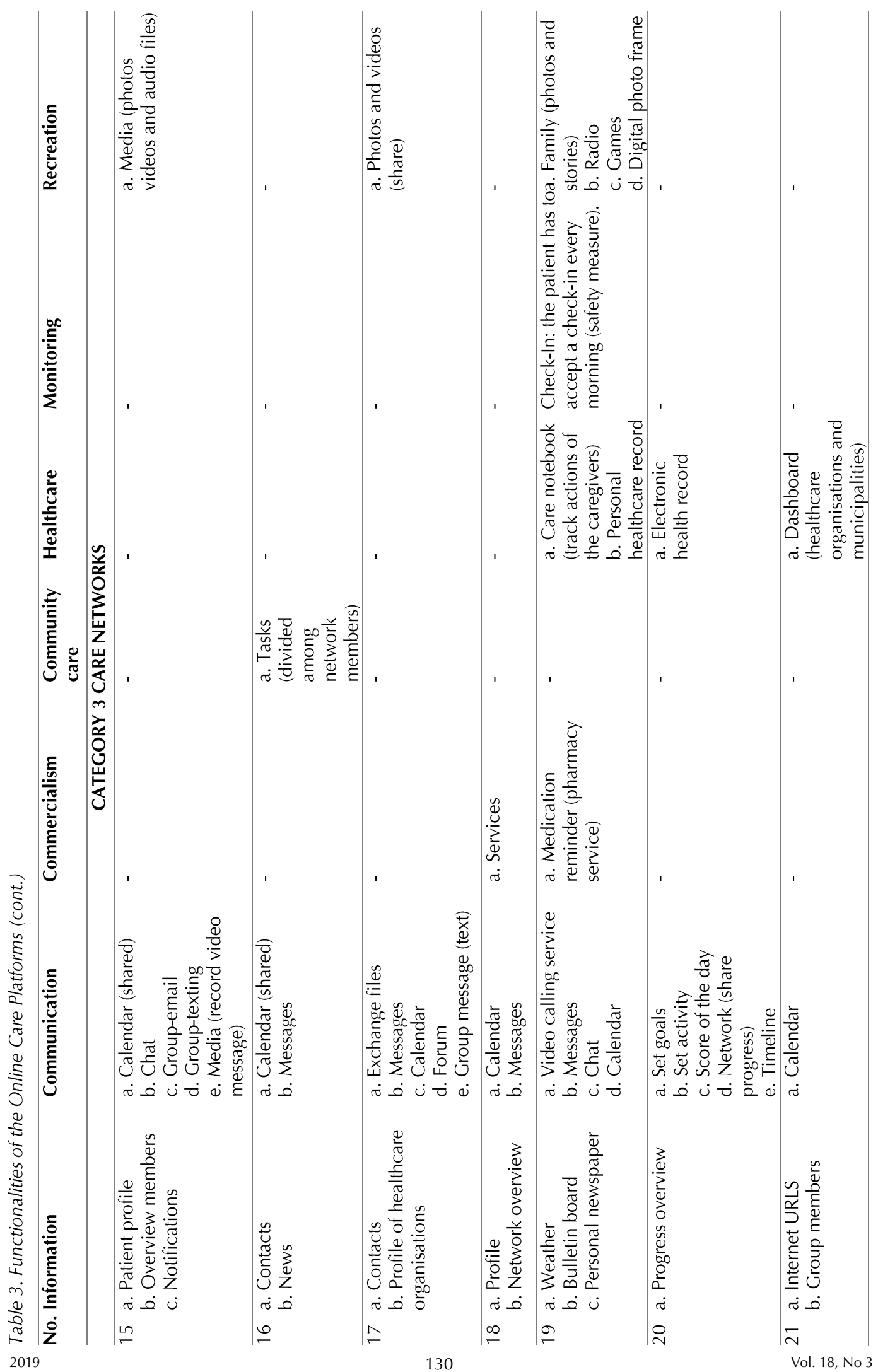



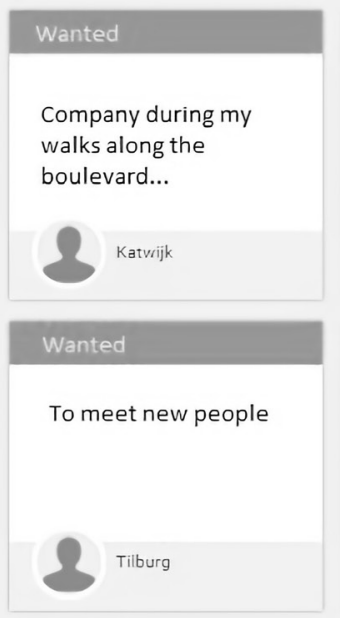

\section{Offered}

Company, gardening

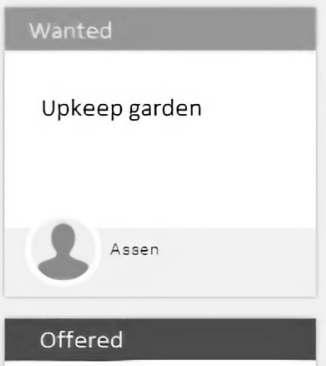

Computer and gardening aid

Raamsdonksveer

\section{Offered}

Company, transportation and computer asisstance

Alphen aan den Rijn

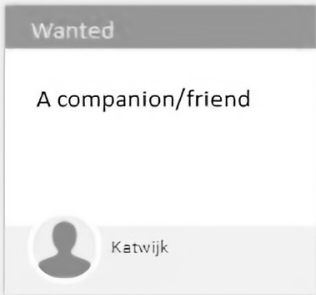

Offered

Housekeeping support

Offered

Handyman, house repairs

Oude Pekela
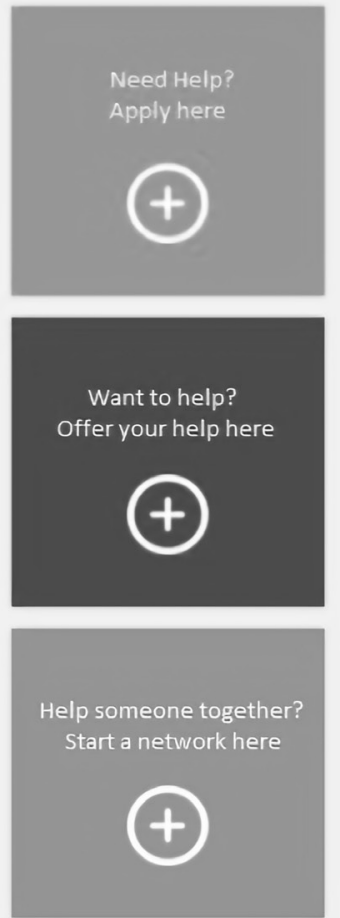

Figure 2. Screenshot of the functionality of the 'Social Marketplace' platform

\section{Consultations with the relevant stakeholders}

As proposed by Arksey \& O'Malley (2005), it was of value to involve the stakeholders, in order for them to provide insights beyond those that were found in the literature searches. Therefore, the description of each online platform was presented to the owner or the administrator via e-mail, so as to confirm the study's findings. Eventually 19 administrators responded to our request and provided feedback. This feedback and the additional information details were, if relevant and applicable, processed into the final platforms' description.

\section{Results \\ Selection process}

The searches in the scientific databases and on the Internet generated 765 potentially relevant documents; based upon their title, 81 abstracts and their platform-descriptions were examined (Figure 1). Eventually, no scientific articles were included after reviewing these 81 abstracts, because they were not about online care platforms or because they were about platforms that were intended for older adults suffering from a specific disease or condition. Thus, the selection process finally yielded 21 documents for the review and they were all retrieved from websites or from online descriptions of their platforms.

\section{Characteristics of the online platforms}

The characteristics of the 21 included platforms are presented in Tables 2 and 3, from which 3 types of platforms were able to be distinguished: Community Care Platforms (9), System Integrator Platforms (1) and Care Network Platforms (11).

\section{Community Care Platforms}

These 9 platforms (BuurtWelzijn, 2017; Care Living Labs, 2018; Coöperatie Thuisverbonden, 2018; Dorpsportaal Burum, 2018; Eerste Verdieping, 2017, 2018; Munity Services, 2018; RO, 2018; Sevagram Connect, 2017; Trivici, 2017; WeHelpen, 2017; WijkConnect, 2018) were all designed, so as to support local communities, by enhancing social cohesion and by encouraging informal care. In order to obtain the objective of a more 'cohesive community', these platforms predominantly offered online functionalities regarding the domains of 'information', 'communication', 'Commercialism' and 'community-care'. A few examples of the aforementioned functionalities were: a) local yellow pages, an online database of local entrepreneurs, shops and services, which granted older adults the opportunity to remotely employ services; b) social marketplace (Figure 2), in which the older adults could ask for, or be offered help, regarding "care-related" 


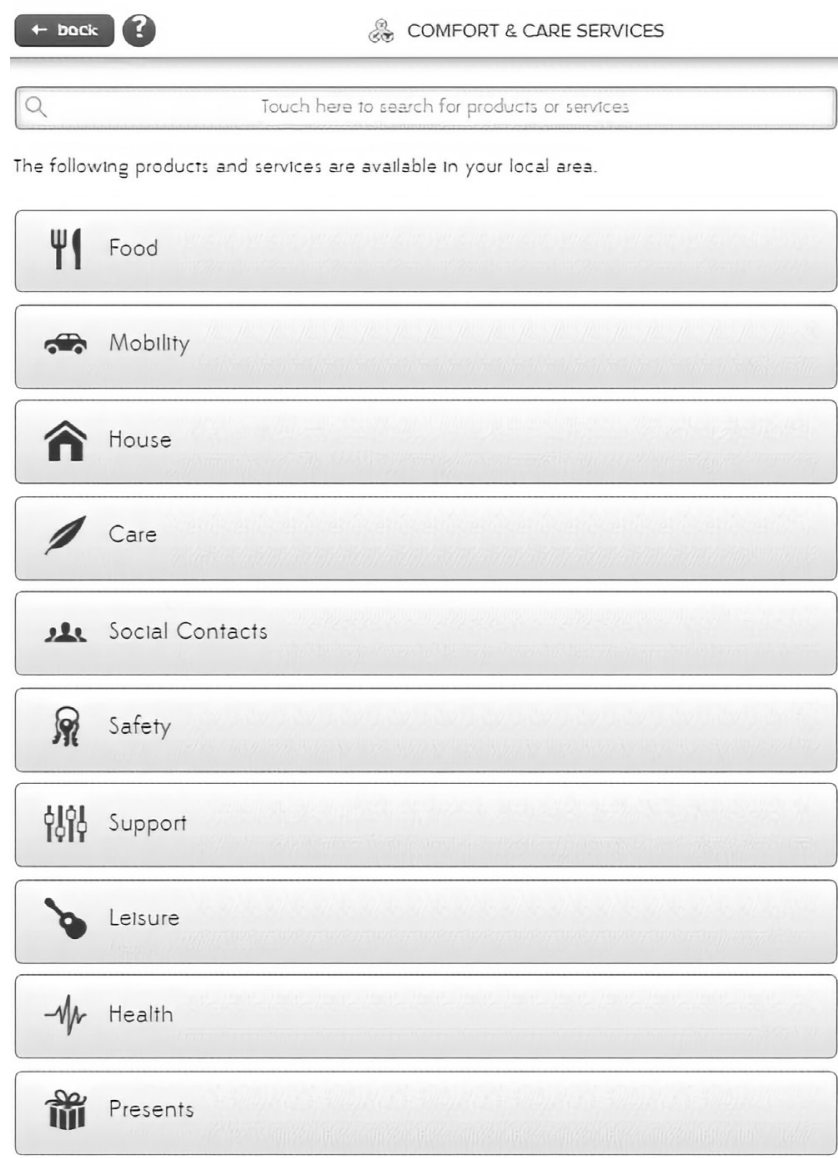

Figure 3. Screenshot of the menu functionality of the 'Comfort and Care Services' platform Cubigo

issues, such as assistance with a garden's upkeep, or shopping for groceries; c) local calendar, in which the older adults could find out about information regarding various activities - for example, groups and/or meet ups regarding hiking, playing card games and creative crafts and so on.

\section{System Integrator Platforms}

One platform, the Cubigo platform (Cubigo, 2018), was a system integrator: a platform which had the capability of integrating existing services and applications into their own software. This platform had a large number of functionalities, within all of the domains that were taken into account during the selection procedure, such as 'information', 'communication', 'commercialism', 'community care', 'health care' and 'monitoring'. A few exemplar functionalities of the platform were: (a) calendar, a customisable 'app', into which several calendars could be integrated, for example, a personal calendar and a local (activity) calendar; (b) comfort and care services (Figure 3), a catalogue and a web shop for numerous care services; and (c) video calling service, a visual communication tool, by which the older adults could contact people in their network.

Care Network Platforms

The remaining 11 platforms (BV, 2018; Caren Zorgt, 2018; Compaan, 2018; ConnectedCare, 2018; Dela, 2018; FamilieNet, 2018; Mantelplan, 2018; MiBida, 2017; Praktikon, 2018; Quli, 2018; ShareCare, 2018) were mainly designed to support (informal) caregivers who wished to coordinate assorted collaborations and (health) care issues for an older person. Consequently, these platforms predominantly offered online functionalities in the domains of 'information' and 'communication'. The 'shared calendar' (Figure 4), by which caregivers could coordinate their care activities, was a key functionality in these care-network platforms.

Table 4 provides many additional platform characteristics. The majority of the platforms were established between 2010 and 2015. The number of registered individuals varied substantially between the platforms. 'Small' platforms had an overall of 1100 to 6000 members and the 'larger' platforms had an overall of 30000 to 65000 members. Some platforms reported on their 'distribution range', by citing the number of organisations or neighbourhoods which had adopted their platform (e.g. 30 municipalities, 10 neighbourhoods or 500 healthcare organisations).

The costs for the purchase and the maintenance of the online platforms' software were mostly reimbursed by neighbourhood organisations, (health) care organisations, or by municipalities (17 out of the 21 platforms). These organisations paid fees that ranged from $€ 500$ to $€ 5000$ per year. In these particular cases, the use of the platform was free of charge for the older adults. In a few cases, (e.g. Companion or Caregivers Plan) the older adults themselves paid an annual fee for them to use a platform. These costs then ranged from $€ 60$ to $€ 240$ per year. 


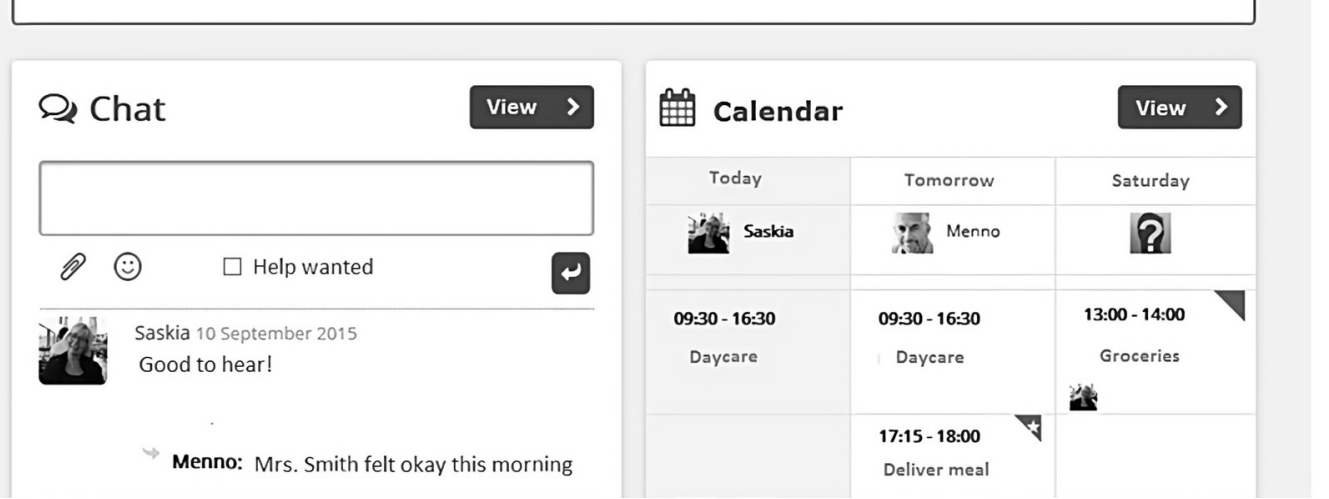

Figure 4. Screenshot of the functionality of the 'Shared Calendar' platform ShareCare

A majority of the platforms $(\mathrm{N}=17)$ operated by using a web-based format and they were independent of any substantial hardware. Of these, 6 could also be accessed via applications for mobile devices (Android and iOS). Three of these platforms were primarily designed as an application for mobile devices, but nonetheless, they could also be accessed via a regular website. Only 1 platform operated on a hardware device and it was not available via a regular website. Most of the platforms $(\mathrm{N}=15)$ had a statement, or information available, regarding 'privacy' and the way in which the personal data was used or protected. Furthermore, many online platform owners $(\mathrm{N}=15)$ included end-users' requirements, experiences and feedback, regarding the 'usability and the content' of their website, for the development and the improvement of their online platform.

\section{Distinctive platform features}

A few platforms were distinctive, since they had a wider employability and the possibility of being integrated with other systems. These were: (a) the Cubigo platform, which had an open structure, for instance, the platform could be integrated with existing services and applications, into their own software. The users could individually determine the layout of the platform's main menu. Thus, this platform could essentially be adapted to every wish and demand of the user, hence, the categorisation of this platform was determined as an 'integrator'; (b) the 'community-care' platforms, which classified their online platforms as a 'method'. These could be purchased and adopted by each neighbourhood. The initiators of this method (such as a municipality, a local resident, or a welfare organisation) were responsible for the success and the implementation of the platform. Consequently, these platforms seemed to be flexible and widely applicable for the various groups of older adults.

\section{Discussion}

This review has provided an overview of the available Dutch online care platforms for community-dwelling older adults. Three types of platforms were identified: (1) Community Care Platforms, which attempt to enhance social cohesion, by interlinking the community-dwelling older adults, with neighbouring informal caregivers and by promoting local activities on a neighbourhood level; (2) Care Network Platforms, which provide older adults, professionals and informal caregivers, with tools to coordinate, plan and communicate about (health) care; (3) System Integrator Platforms, which interconnect a variety of functionalities. The majority of the online platforms operate by using a web-based format and are independent of any substantial hardware. The number of registered individuals varies per platform from between 1100 and 65000 .

This scoping review has shown the existence of a considerable number of comparable online care platforms. It took a great amount of effort to retrieve the relevant information from the majority 


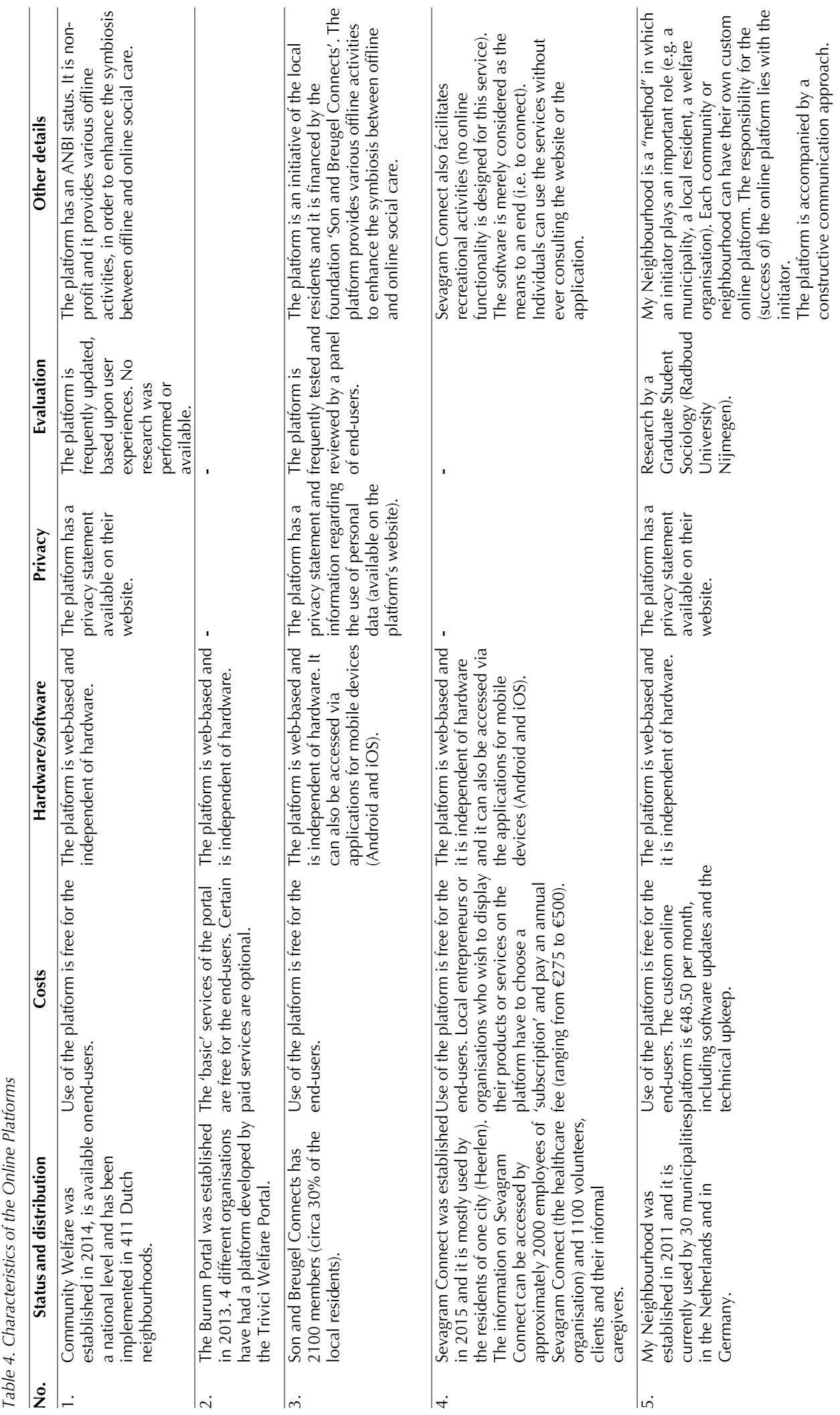




\section{A typology of online care platforms}

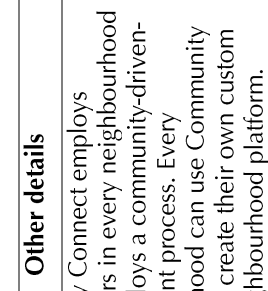

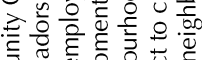

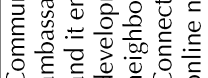

焉

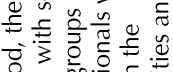

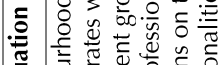

吾

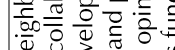

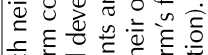

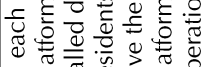

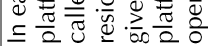

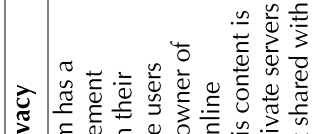

.)

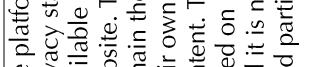

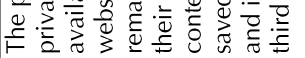

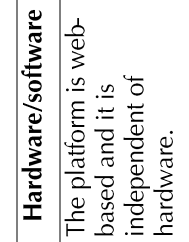

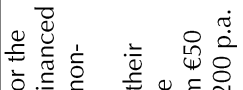

足.

40

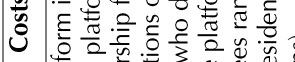

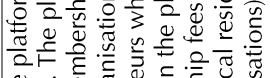

这

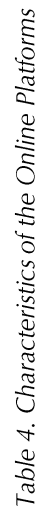

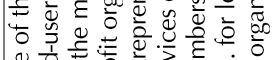
嵌

造

Iี

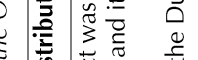

-

空

紊

जै

है

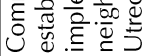

ف

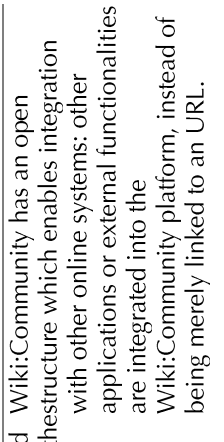

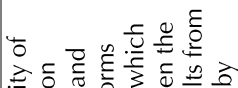

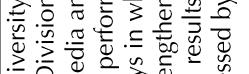

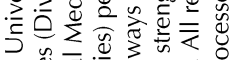

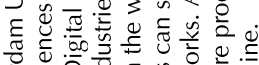

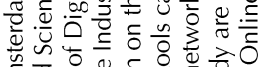

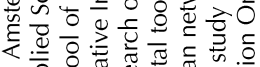

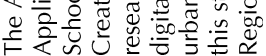

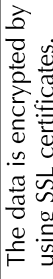

$\frac{1}{9}$

$\therefore$.

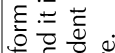

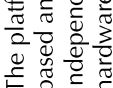

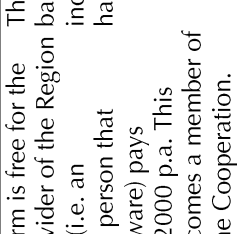

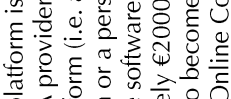

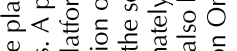

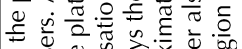

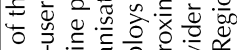

论

. 蛋.

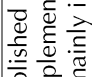

है है

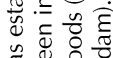

㲾芉 $8 \frac{\pi}{0}$

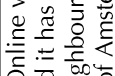

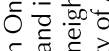

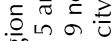

षे워

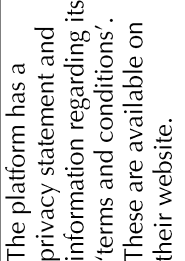

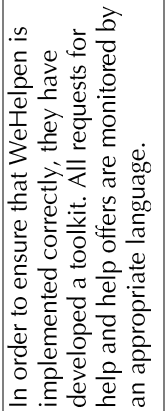

可

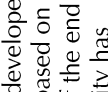

要

旅

중

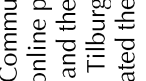

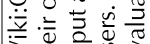

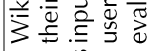

$\frac{1}{3}$

$\frac{1}{2}$

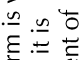

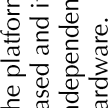

的空.

$\stackrel{8}{\circ} \stackrel{0}{ \pm}$

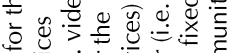

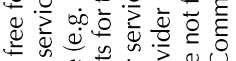

는

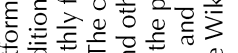

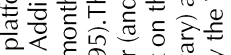

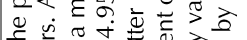

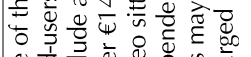

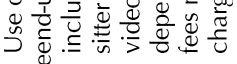

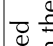

可

紫要

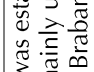

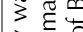

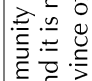

है

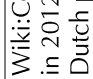

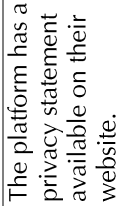

$\frac{1}{3}$

.$\Perp \overline{0}$

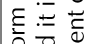

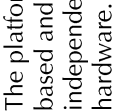

흔

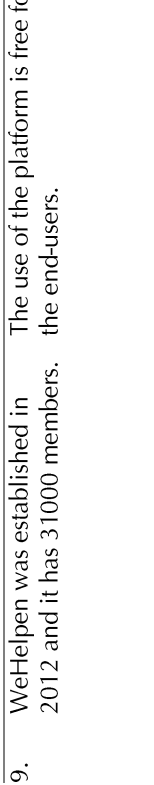




\section{A typology of online care platforms}
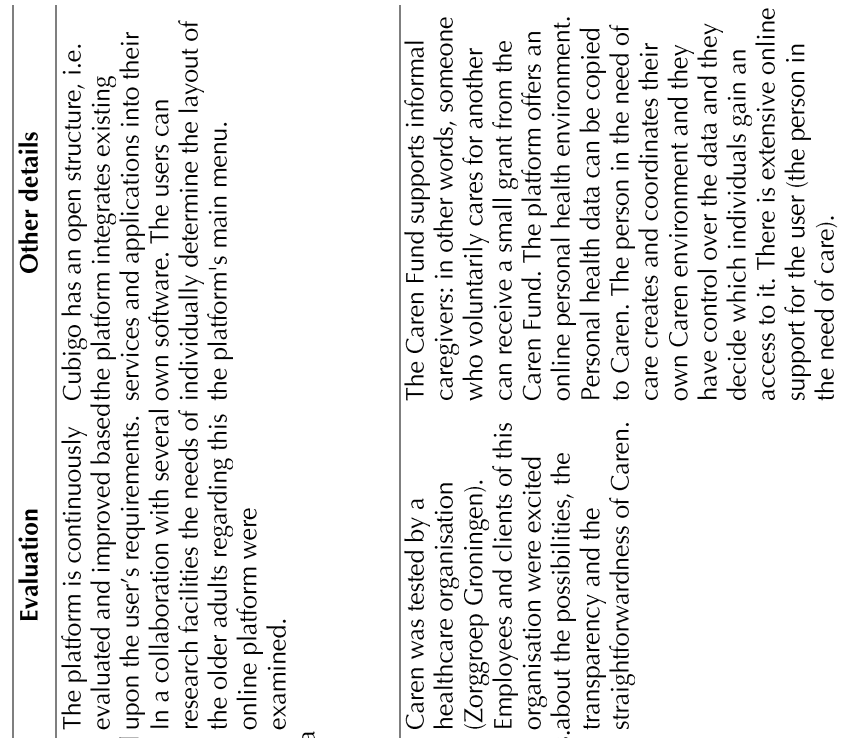

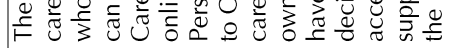

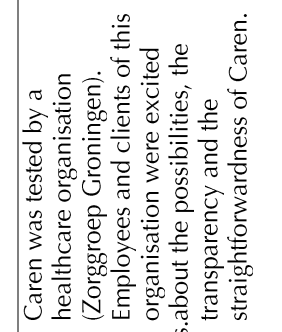

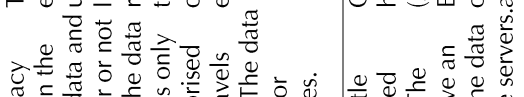

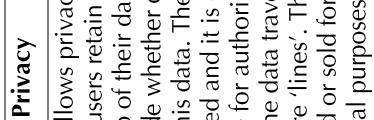

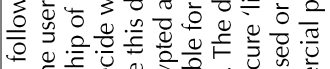

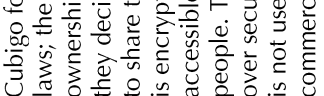
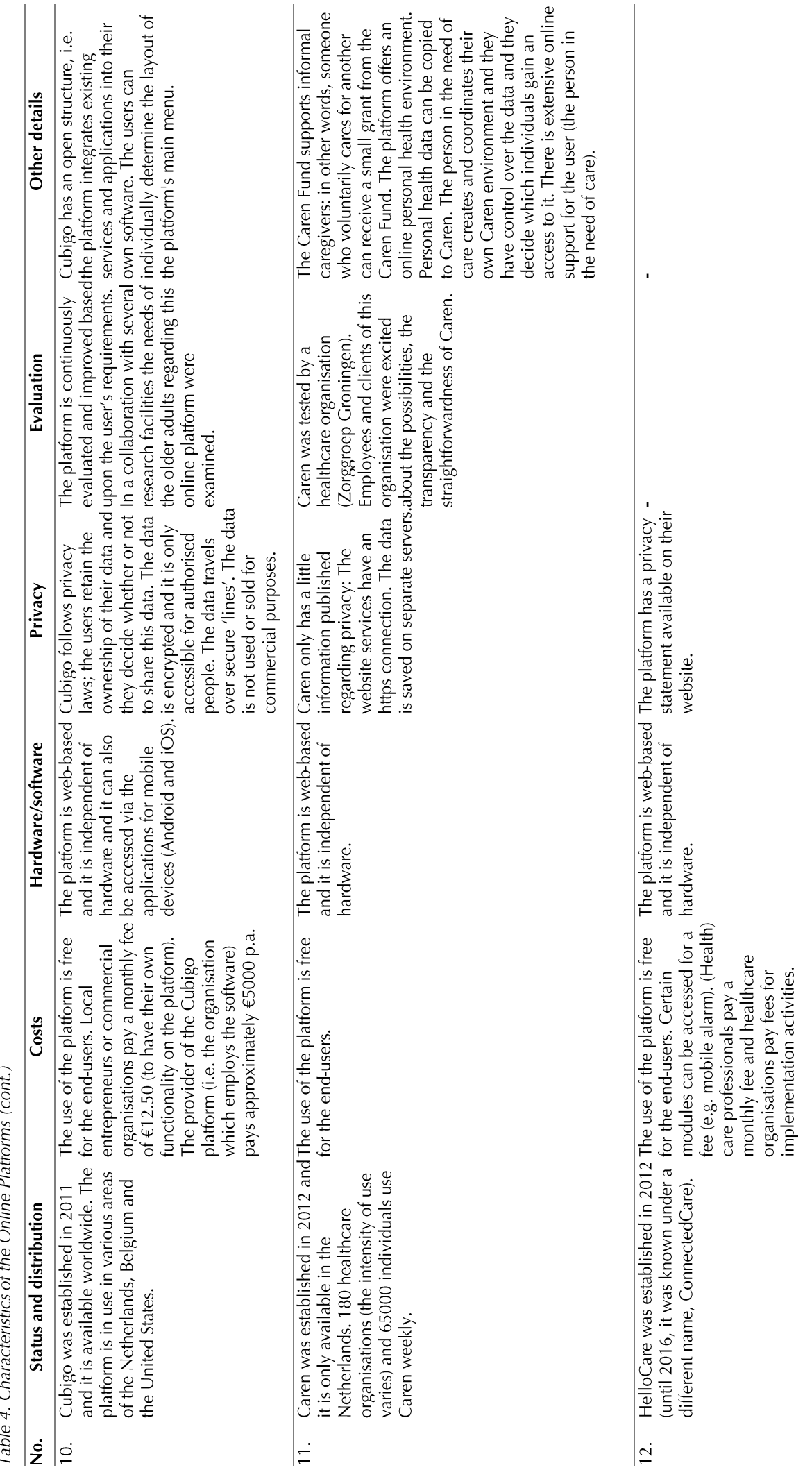


\section{A typology of online care platforms}

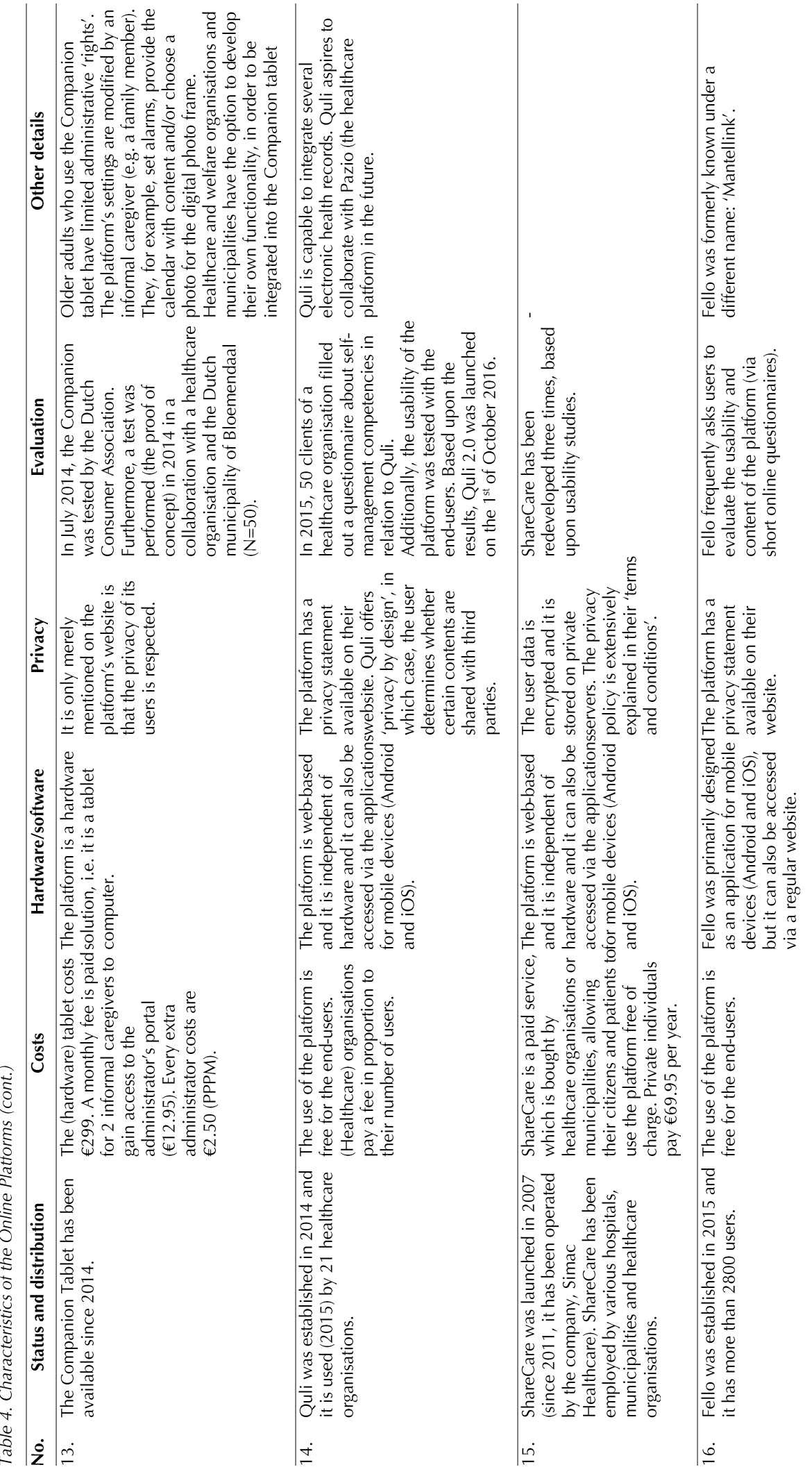




\section{A typology of online care platforms}

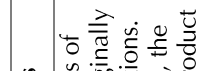

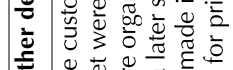 \\ ठ

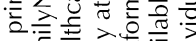

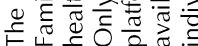

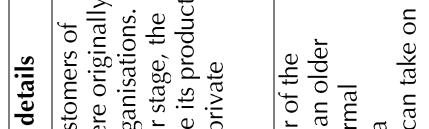

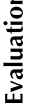

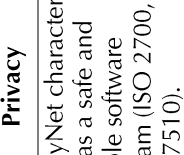

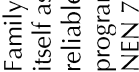
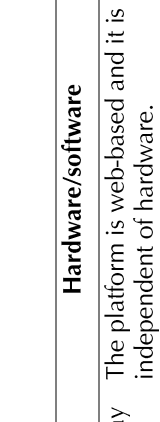

(1)

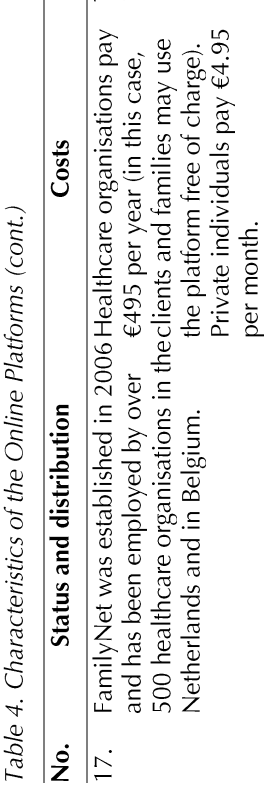

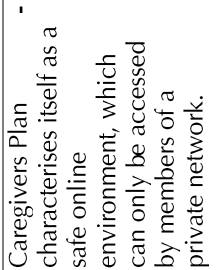

里

告

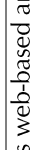

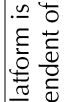

要

인

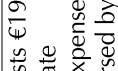

过这起

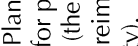

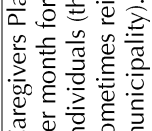

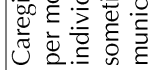

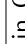

牙

$\frac{\sqrt{\frac{0}{30}}}{\frac{\pi}{20}}$

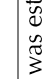

$\frac{\pi}{\frac{\pi}{2}}$

$\sum_{\substack{20 \\ \frac{\omega}{20}}}^{\frac{2}{20}}$

娄

$\stackrel{\infty}{\circ}$

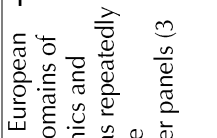

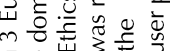

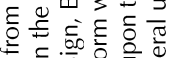

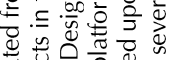

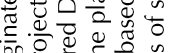

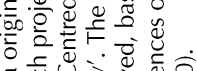

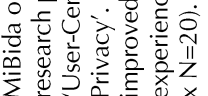
䎡递

?

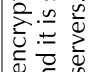
을

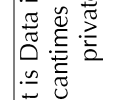

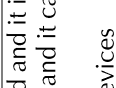

总离造

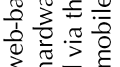

उ

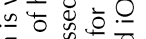

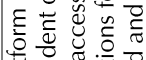

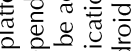

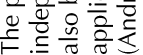

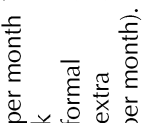

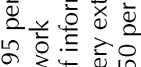

象

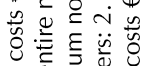

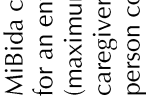

官

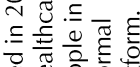

选

응

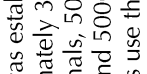

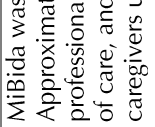

के

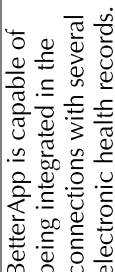

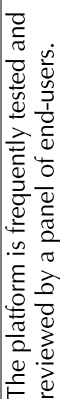

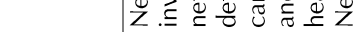

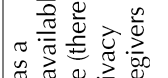

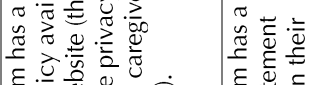

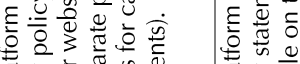

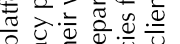

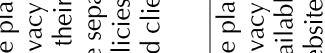

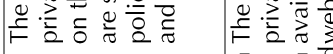

离

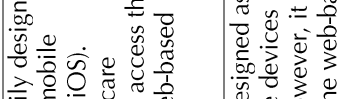

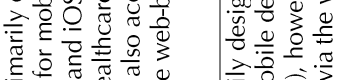

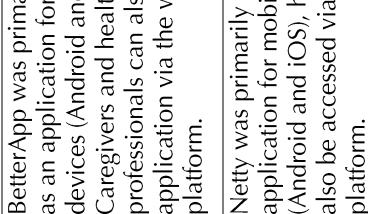

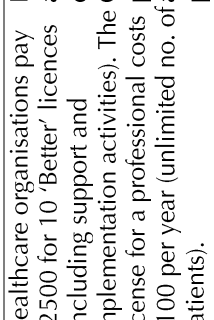

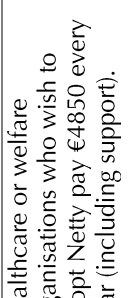

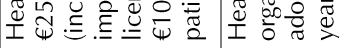

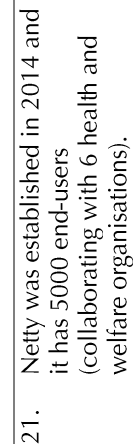


of these online platforms. Thus, for older adults, it may be challenging to discover what a platform's focus is and which available services it has. In addition, the researchers ascertained that some platforms were exclusively 'tailor-made' for small regions, such as for a neighbourhood.

Online care platforms for older adults have not yet been adopted onto a large scale, nor are they widely employed. These findings suggest that it is challenging to successfully exploit these online care platforms. A system integrator, or a platform with an open source is, therefore, perhaps a promising 'type', since it has the potential to interconnect with a variety of functionalities, systems and moreover, it is likely to prevent fragmentation. In other words, this platform type can help to reduce the number of separate platforms and applications for older adults by integrating them within one single platform (Aminpour, Sadoughi, \& Ahamdi, 2014; Conte et al., 2017; Cresswell, Mozaffar, Lee, Williams, \& Sheikh, 2017; Mulder, Hartog, Zijda, \& Gorp, 2017).

Most of the online platform owners reported on and wanted the end-users' requirements, experiences and feedback, on the 'usability and the content' of their website, for the development and the improvement of their product. This 'owner research' had the sole objective of determining whether a certain platform had a marketable value. No research by platform owners, or by research institutes, has yet focused on the impact, or on the effects that are related to the online platforms' initial goals.

This study excluded several online platforms, because they were no longer available (i.e. 'online'). Due to the fast changing world of (health) care innovations that coincides with a highly competitive environment and with a pressure to achieve results; these platforms 'come and go' quickly.

\section{Limitations of the review}

Despite the study's efforts to conduct a comprehensive search, some relevant online care platforms may not have been discovered. Furthermore, due to the lack of any previous research in this field, this scoping review has been based solely on grey-literature reports. All sorts of documents, such as web pages, reports, or online descriptions about these platforms, formed the basis for this review.

\section{Conclusion}

This scoping review has shown the existence of a considerable number of comparable online care platforms, which can be divided into three types: Community Care Platforms, Care Network Platforms, and System Integrator Platforms.

The results have provided an insight into how these platforms should be categorised, which in turn, has allowed for one to have a more adequate discourse about this particular theme. The misperceptions regarding the nature and the capabilities of these online platforms are now able to be somewhat alleviated. Furthermore, the typology of online platforms can better guide the interested users, such as the older adults, the professionals, the informal caregivers and the municipalities, in choosing a suitable platform.

Researchers should, to a greater extent, investigate if these online care platforms have added value and do indeed fulfil their promise in tackling the problems that have arisen due to the current transitions in health care. It should be investigated whether these online care platforms indeed do have a positive impact on aging-inplace, solidifying social cohesion, whilst at the same time, supporting older adults in coordinating or managing their care, as well as in enhancing the self-reliance of the older adults.

\section{Acknowledgements}

The funding for this study was provided by The Netherlands Organisation for Health Research and Development (ZonMw). Funding was also provided by Zuyd University of Applied Sciences. Both funding bodies had no role in the collection, analysis, and interpretation of data and in writing the manuscript. The authors thank April Boessen and Ger Cremers for their help in reviewing and assessing the online platforms.

\section{References}

Aminpour, F., Sadoughi, F., \& Ahamdi, M. (2014). Utilization of open source electronic health record around the world: A systematic review. Journal of Research in Medical Sciences: The Official Journal of Isfahan University of Medical Sciences, 19(1), 57-64.

Arksey, H., \& O'Malley, L. (2005). Scoping studies: towards a methodological framework. International Journal of Social Research Methodology, 8(1), 19-32.

Bankauskaite, V., Dubois, H. F. W., \& Saltman, R. B. (2007). Chapter 2. Patterns of decentralization across European health systems. In E. O. o. H. S. a. P. Series (Ed.), Decentralization in Health Care Strategies and outcomes Open University Press McGraw-Hill Education.

Boll, F., \& Brune, P. (2016). Online Support for the Elderly - Why Service and Social Network Platforms should be Integrated. Procedia Computer Science, 98(Supplement C), 395-400. https://doi. org/10.1016/j.procs.2016.09.060

Bryman, A. (2016). Social research methods: Oxford university press.

BuurtWelzijn. (2017). BuurtWelzijn Alle digitale mogelijkheden in de buurt. Retrieved from https://www. 
mijnbuurtwelzijn.nl/Home/HoeWerktHet

BV, V. (2018). Nettie \#1 oplossing voor zelfstandig, prettig en veilig thuis. Retrieved from https://www.nettie.nu/

Care Living Labs. (2018). Online Neighborhoods. Retrieved from http://www.zorgproeftuinen.be/en/en/ platforms/online-neighborhoods

Caren Zorgt. (2018). Deel veilig informatie binnen je eigen zorgnetwerk. Retrieved from https://www. carenzorgt.nl/welcome

Colquhoun, H., Levac, D., \& O'Brien, K. (2010). Scoping studies: advancing the methodology. Implementation Science, 5(1), 1-9. Retrieved from

Compaan. (2018). De meest complete tablet voor ouderen Retrieved from https://www.uwcompaan.nl/

Companje, K., (2013). Hervorming van langdurige zorg: van verzorgingsstaat naar participatiesamenleving. Tijdschrift voor gezondheidswetenschappen, 91(8), 453-454.

ConnectedCare. (2018). Zorgen doe je samen met HalloZorg. Retrieved from http://www.hallozorg.nl/

Conte, R., Sansone, F., Grande, A., Tonacci, A., Napoli, F., Pala, A. P., Landi, P. (2017, 22-24 June 2017). Development of an integrated ICT system for data production, standardization and elaboration in health \& care. Paper presented at the 2017 E-Health and Bioengineering Conference (EHB).

Cooperatie Thuisverbonden. (2018). Zelf doen, samen doen, laten doen. Retrieved from https://www. sonenbreugelverbindt.nl/

Cramm, J. M., Twisk, J., \& Nieboer, A. P. (2014). Selfmanagement abilities and frailty are important for healthy aging among community-dwelling older people; a cross-sectional study. BMC Geriatr, 14(1), 1-5. https://doi.org/10.1186/1471-2318-14-28

Cresswell, K. M., Mozaffar, H., Lee, L., Williams, R., \& Sheikh, A. (2017). Safety risks associated with the lack of integration and interfacing of hospital health information technologies: a qualitative study of hospital electronic prescribing systems in England. BMJ Quality \&amp;amp; Safety, 26(7), 530.

Cubigo. (2018). Langer zelfstandig thuis wonen Retrieved from http://www.cubigo.com/nl

Dela. (2018). Fello. Je nieuwe familieagenda Retrieved from https://getfello.com/

Dorpsportaal Burum. (2018). Dorpsportaal Burum Retrieved from https://burum.openportaal.nl/

Eerste Verdieping. (2017). Community Platform voor Sociale Netwerken en Online Samenwerking Retrieved from https://www.wikiwijk.nl/

Eerste Verdieping. (2018). Internet Communities Het verbinden van mensen door nieuwe technologie en online toepassingen innovatief te combineren Retrieved from http://www.eersteverdieping.nl/

FamilieNet. (2018). Familienet verbindt familie met zorg Retrieved from https://www.familienet.nl/

Foster, L., \& Walker, A. (2015). Active and successful aging: a European policy perspective. Gerontologist, 55(1), 83-90. https://doi.org/:10.1093/geront/ gnu028

GrandCare. (2016). GrandCare Systems: The Best in Senior Care Technology. Retrieved from https:// www.grandcare.com/

Grant, M. J., \& Booth, A. (2009). A typology of reviews: an analysis of 14 review types and associated methodologies. Health Info Libr J, 26(2), 91-108. https:// doi.org/10.1111/j.1471-1842.2009.00848.x

Krijgsman, J., Eertink, H., Leeuw, J. v. d., \& Zondervan, R. (2012). Praktisch model voor ICT platformen bij welzijn en zorg op afstand. Retrieved from https:// www.nictiz.nl/wp-content/uploads/2012/06/Praktisch-model-voor-ICT-platformen-voor-welzijn-enzorg-op-afstand-1.0.pdf

Makai, P., Perry, M., Robben, S. H., Schers, H., Heinen, M., Olde Rikkert, M. G., \& Melis, R. J. (2014a). Which frail older patients use online health communities and why? A mixed methods process evaluation of use of the Health and Welfare portal. J Med Internet Res, 16(12), e278. https://doi. org/10.2196/jmir.3609

Makai, P., Perry, M., Robben, S. H., Schers, H. J., Heinen, M. M., Olde Rikkert, M. G., \& Melis, R. F. (2014b). Evaluation of an eHealth intervention in chronic care for frail older people: why adherence is the first target. J Med Internet Res, 16(6), e156. https://doi.org/10.2196/jmir.3057

Mantelplan. (2018). MantelPlan als multidisciplinair communicatieplatform. Retrieved from http://mantelplan.nl/home

Mibida. (2017). Het begin bij communicatie Retrieved from http://www.mibida.nl/

Mulder, A. W., Hartog, M. W., Zijda, D.-J., \& Gorp, v. A. (2017). Maatschappelijke Informatievoorziening Dossier e-health - zicht op opschaling. Den Haag: De Haagse Hogeschool in samenwerking met De E-Health Academie Delft.

Munity Services. (2018). Samen maken we een betrokken buurt. Retrieved from https://www.mijnbuurtje.nl/

Newman, J., \& Tonkens, E. (2011). Participation, responsibility and choice: summoning the active citizen in western European welfare states: Amsterdam University Press.

Praktikon. (2018). BeterApp De Functionaliteiten Retrieved from http://www.beterapp.nl/?page_ id $=1012$

Quli. (2018). Quli helpt om zo zelfstandig en gezond mogelijk te leven. Retrieved from https://www.quli.nl/

RO. (2018). Regio Online De Lokale en Regionale Nieuwsverspreider Retrieved from https://www. regioonline.nl/

Robben, S. H., Heinen, M. M., Makai, P., Olde Rikkert, M. G., Perry, M., Schers, H. J., \& Melis, R. J. (2013). [Reducing fragmentation in the care of frail older people: the successful development and implementation of the Health and Welfare Information Portal]. Tijdschr Gerontol Geriatr, 44(2), 59-71. https://doi.org/10.1007/s12439-013-0014-8

Van der Schoot, R., (2014). Hervorming van zorg en ondersteuning: de vertaling van de transities binnen de gemeente. . Retrieved from http://www.vilans. nl/docs/vilans/publicaties/VILANS_ZORGTRANSITIE_DIGI.pdf

Sevagram Connect. (2017). Welkom bij Sevagram Connect. Retrieved from https://sevagramconnect.nl/

ShareCare. (2018). ShareCare is samen zorgen. Thuis of in woonzorg Retrieved from https://zorgsite.nl/ member/login

Trivici. (2017). Dorpsportaal Burum Retrieved from 


\section{A typology of online care platforms}

\section{http://www.trivici.nl/?page_id=619}

Van Hees, S. V. (2017). The making of ageing-in-place: perspectives on a Dutch social policy towards lifecyclerobust neighbourhoods, Maastricht University.

Vedel, I., Akhlaghpour, S., Vaghefi, I., Bergman, H., \& Lapointe, L. (2013). Health information technologies in geriatrics and gerontology: a mixed systematic review. J Am Med Inform Assoc, 20(6), 1109-1119. https://doi.org/10.1136/amiajnl-2013-001705

WeHelpen. (2017). Hulp zoeken en aanbieden in de buurt. Retrieved from https://www.wehelpen.nl

WijkConnect. (2018). Welkom in Wittevrouwen Retrieved from https://www.wijkconnect.com/utre-

\section{cht/wittevrouwen/}

Willard, S., Cremers, G., Man, Y. P., van Rossum, E., Spreeuwenberg, M., \& de Witte, L. (2018). Development and testing of an online community care platform for frail older adults in the Netherlands: a user-centred design. BMC Geriatr, 18(1), 87. https:// doi.org/10.1186/s12877-018-0774-7

De Jong,.Y (2015). Overzicht Digitale Communicatieplatforms om te communiceren binnen de zorg en de zorg te delen Retrieved from http://www. expertisecentrummantelzorg.nl/Site_EM/docs/pdf/ Overzicht-aanbieders-digitalecommunicatie-zorgjan-2015.pdf 